\title{
Traditional Ecological Knowledge: Learning from Indigenous Practices for Environmental Sustainability. Edited by Melissa K. Nelson and Dan Shilling. 2018. Cambridge University Press, New York, NY. 276 pp.
}

\author{
Christopher D. Stiegler ${ }^{*}$ \\ ${ }^{1}$ Department of Anthropology, University of Arkansas, Fayetteville, USA. \\ "cstiegle@uark.edu
}

Received June 18, 2019

Accepted November 15, 2019

Published December 4, 2019

OPEN $\partial_{\text {ACCESS }}$
DOI $10.14237 / \mathrm{ebl} \cdot 10.1 .2019 .1606$

Copyright (c) 2019 by the author(s); licensee Society of Ethnobiology. This is an open-access article distributed under the terms of the Creative Commons Attribution-NonCommercial 4.0 International Public License (https://creativecommons.org/licenses/by-nc/4.0), which permits non-commercial use, distribution, and reproduction in any medium, provided the original author and source are credited.

Ecological knowledge guides sustainable behaviors and outcomes within human cultures and promotes human survivability. Works in this edited volume seek to understand how non-Western traditional human knowledge systems enable cultures to perceive their world in effective and ultimately productive ways. The editors, Melissa K. Nelson and Dan Schilling, are well-qualified to examine traditional ecological knowledge (TEK) given their more than sixty years combined experience as ecologists, indigenous activists, environmental historians, and scholars of environmental ethics. This book arrives at a time when sustainable behaviors and diverse cultural worldviews are vital for the mitigation of climate change and other imminent ecological crises. There is a growing need for human-environment reciprocity that distances itself from Western commodification of and detachment from nature. This volume presents views of environmental sustainability from authors from different backgrounds to deeply explore perspectives on environmental ethics that promote human survivorship. Specifically, this volume considers the relationship between Western and Native science. Native science is a participatory, "indigenous relationship to land, plants, animals, community, self, cosmos spirit, and the creative animating processes of life" (p. 15), whereas Western science tends to view humans as separate from nature. Within the Western paradigm, nature is considered a commodity to be used for human consumption. The goal of this book is to understand the relations between these worldviews. There are 14 chapters and a total of 18 authors. The authors consider TEK's practical applications to sustainability and ultimately human evolutionary prosperity.

While this book has relevance to ethnobiology and ecological anthropology, it will also resonate with general anthropologists, including scholars of paleoanthropology. In Schilling's introductory chapter, he suggests that during the Pleistocene Era, hominins lived sustainably because they sensed their existence was linked to the environment's well-being. It seems reasonable to me that hominin populations who were successful at transmitting ecological knowledge would share an evolutionary advantage over populations unable to do so. From prehistoric lithics to modern industrial technology, Schilling suggests sustainability is a moral rather than technological concern that depends on Homo sapiens' views of the natural environment.

In the chapter by Cajete and the chapter by Whyte, these authors argue the differences between Native science and Western science rest primarily in understanding the relationship between humans and nature. They state that some indigenous peoples consider themselves born as members of reciprocal and local human and nonhuman biological communities. Within these communities, humans develop relationships with other organisms and learn from them adaptive ecological knowledges. Many Western scientists do not consider these knowledges, nor do they have access to them when they engage in their studies. 
In his chapter, Whyte suggests that understanding TEK has practical applications. Regarding the everpresent threat of climate change, an array of different knowledge systems is needed. Knowledges of how to live adaptively with nonhumans and the environment can lead to sustainable development and proper management of the natural world. He accurately claims that the Western worldview in fact contributes to climate change because it ultimately facilitates the destruction of environments. In my mind, another way of thinking of this is that the cultural knowledge of people inhabiting ecosystems for thousands of years transmits effective and consistent ecological knowledge that may not rest within Western scientific explanatory parameters. The dichotomous, materialistic, and commercial view of the Scala Naturae existing in Western Judeo-Christian doctrines does not understand the reciprocal human-environment relationships associated with emotional and spiritual responses toward nature. The view of humans as part of nature switches nature from commodity to, as Martinez calls it, a kincentric ecology, where all life exists in symbiotically mutualistic and phylogenetically relevant ways with all other lifeforms.

In the chapter written by Kimmerer, she argues TEK is an alternative to Western materialism. The living world is not to be viewed as a collection of extractable resources, but as a relationship with responsibilities that humans have to non-human persons. For example, if humans view plants as teachers rather than commodities, then they can learn evolutionarily adaptive knowledge, such as which plants should be used for medicine and food, and why. One could argue from a functionalist viewpoint that plants of high cultural salience, such as sweetgrass for the Anishinaabe people, are teachers most willing to assist human cultures and their survival by acting as resources. Additionally, salient resources are often linguistically recognized, as stated in the chapter authored by Armstrong. He explains that the Syilx people have a word, tmixw, that refers to the ecology of the land and all lifeforms that are culturally important. McGregor also takes a critical view of materialistic Western science and suggests the future of ecological sustainability depends on ecofeminism. Unlike Western masculine materialism, ecofeminism calls for a perspective where women and ecology are not subordinate to men and materialism; no ideology is dominant.

While these previous authors focus on the differences between TEK and scientific ecological knowledge (SEK), the chapter by Nelson and Vucetich tries to reconcile the two knowledge systems. They claim the central focus of SEK is taken to be that knowledge is valuable for its own sake in order to manipulate the world for human material gain, whereas TEK seeks to better understand nonhuman persons for the knowledge of how best to care for one another in sustainable ways. Long Term Ecological Research is their answer to merging the two. It considers the assignment of personhood to nonhuman organisms as a means to instill values for these creatures in people and promote humanenvironment sustainability.

These chapters masterfully achieve an understanding of the importance of the relationship between cultural conservation and ecologically related behaviors. Indeed, this book indicates to the readers the immediate importance of TEK conservation. For example, in their chapter, Wolfgramm et al. suggest scientists may use indigenous botanical knowledge to innovate new pharmaceuticals or new strands of drought-resistant crops. Looking to the future, human sustainability necessitates worldviews which implement and advance traditional ecological knowledge extensively.

As a student of anthropology and ethnobiology, this volume helps me to understand humans and their evolutionary path more fully. Knowledges, like genes, are transmitted from generation to generation, and knowledges which promote human survivability are selected for through the generations creating systems of information that, while not scientifically rigorous, are every bit as ecologically informative. Like a part of human physiology, these knowledges allow humans to successfully navigate their ecological habitats. Truly, this volume illuminates the adaptiveness of traditional ecological knowledge as humanity tries to survive in a world plagued by climate change and radically unraveling ecosystems. 